\title{
BYBLIS IN CULTIVATION IN THE TROPICS AND IN TEMPERATE CLIMATES
}

\author{
GREGORY ALLAN • Birmingham • United Kingdom • greg_w_allan@yahoo.com \\ CINDY CHIANG・Singapore・nepceph@gmail.com
}

This article has been written based mostly on the authors' experiences in growing Byblis in the UK and in Singapore. It is hoped that growers in regions with different climates will be able to extrapolate from the information provided here, adjusting the methods described below to suit their own growing conditions. Hopefully much of the information provided here is universal in its application.

\section{Introduction}

If any genus of carnivorous plants deserves to be better known, both by horticulturalists and botanists, it is Byblis. The common name (ironically rarely used by enthusiasts) for the genus is "rainbow plants", on account of the prismatic effect that can be produced when the sun shines on their copiously-produced sticky glands. All species follow a basic morphological plan: they have a central stem from which radiate numerous filiform leaves and scapes with showy flowers that typically have purple petals (although white forms of most species are known) and vivid yellow anthers. Virtually all parts of the plants are covered in mucilage-tipped stalked glands (colloquially referred to as "tentacles"), which efficiently capture small insects, as well as microscopic sessile digestive glands. Another interesting characteristic of the genus is the presence of pulvini in most, if not all, species. Pulvini are swellings at the base of pedicels which, usually after successful pollination, utilize hydraulics to bend the pedicel, and consequently the developing fruit, downwards towards the ground. This phenomenon was discovered by Brian Barnes in the early $21^{\text {st }}$ century.

From the time of Charles Darwin until the late $20^{\text {th }}$ century, Byblis were classified as passive carnivores. However, towards the end of the century, doubts emerged as to whether Byblis were able to produce digestive enzymes at all, and they frequently came to be regarded as merely protocarnivorous plants. Subsequent tests conducted during the first part of the $21^{\text {st }}$ century did demonstrate enzyme production and nutrient sequestration, confirming Byblis as a true carnivore. The most recent research suggests that Byblis tentacles collapse inwards in response to prey capture, which indicates that they ought to be regarded as active carnivores. In nature, all species have been observed to play host to bugs from the genus Setocoris, which feed on the plants' ensnared prey without becoming trapped by the sticky glands. It is also strongly suspected that Byblis spp. obtain nutrition indirectly via the Setocoris bugs in a manner similar to Roridula and their commensal Pameridea bugs.

\section{The species of Byblis}

All Byblis species inhabit Australia, although one or more have also been recorded from the southern tip of the island of New Guinea. All grow in very nutrient-poor habitats which are subject to regular wildfires. They are commonly found sympatric with various Drosera and Utricularia species and, in Australia's Cape York Peninsula and New Guinea, Nepenthes. Two Byblis species are perennials, whilst the other six are annuals.

The perennial species: Byblis gigantea and B. lamellata

Byblis gigantea is listed on the IUCN Red List as critically endangered and is found in a handful of sites within the Perth metropolitan area (which has predictably unfortunate implications for 
its conservation) plus a few sites in the adjacent Darling Range. Byblis lamellata inhabits a small area approximately $275 \mathrm{~km}$ north of Perth. Both species are found in nutrient-poor substrates consisting entirely or primarily of sand, often growing alongside tuberous and pygmy Drosera species. The perennial Byblis are bushy plants, very similar in appearance, producing leaves that can exceed $25 \mathrm{~cm}$ in length, with stout stems reaching more than $40 \mathrm{~cm}$ in height that often branch, and bearing beautiful flowers which are several $\mathrm{cm}$ in diameter and usually have deep purple petals. Healthy adult specimens are a magnificent sight (Fig. 1). Seedlings produce increasingly long leaves prior to stem-production, until they superficially resemble large (unrelated) Drosera filiformis plants. In nature, plants produce foliage from autumn onwards, dying back during mid to late summer. Re-growth from the roots, or leaf axils on spent stems, occurs when cooler

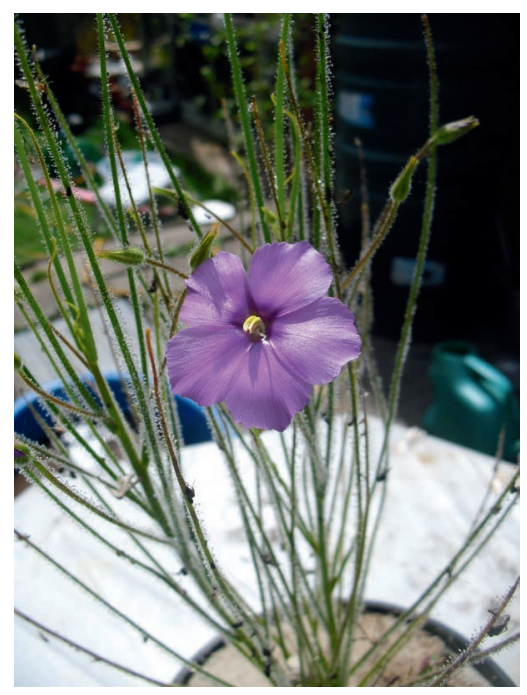

Figure 1: Byblis gigantea. and damper conditions return, occasionally after wild fires have depleted competing plants. Byblis gigantea is actually slightly smaller than B. lamellata, and inhabits conditions that are rather wetter, particularly during the southern Western Australian wet season. Indeed, at least climatically, and in respect to its well-drained nutrient-poor substrate, the habitat of B. lamellata has been described as resembling somewhat that of Drosophyllum lusitanicum. Although there are also significant differences between the habitats of these two unrelated species, it is useful from a horticultural perspective to note that they grow well side by side in similar substrate with a similar watering regime.

\section{The annual Byblis species}

All annual Byblis are endemic to monsoon tropical to semi-arid regions of northern Australia plus southern New Guinea. Germination occurs as the wet season commences (often after fires) and the reproductive cycle is completed before seasonal dry conditions prevail. Anther length compared with filament length has been a useful characteristic to identify different Byblis species. However, in the absence of flowers, tentacle length at the mid sections of leaves can also be useful (see Table 1). More in-depth studies are needed to verify whether the three characters described in Table 1 are reliable and stable characters across the variation found in annual Byblis taxa.

The following is a general introduction to each recognized species, and a description of each as they generally appear in cultivation (as opposed to a technical discussion of taxonomy):

\section{Byblis aquatica}

This species is usually reported as growing in areas which, throughout the wet season, become inundated so that adult plants grow in several $\mathrm{cm}$ of water, although inundation is not necessary in cultivation. In cultivated forms, the leaves are usually $2-3 \mathrm{~cm}$ in length and furnished with extremely short tentacles. Some forms are robust with a stem that is self-supporting up to at least $10 \mathrm{~cm}$ in length, whilst other forms are more delicate in appearance. Unlike most species (but in common with $B$. liniflora), the anthers are shorter than the filaments. Although the flowers are small, the 


\begin{tabular}{|l|l|l|l|}
\hline \multicolumn{3}{|c|}{$\begin{array}{l}\text { Table 1. Comparison of Byblis tentacles at the mid sections of leaves, observed on the } \\
6 \text { annual species grown at the same time under identical conditions in Singapore. }\end{array}$} \\
\hline Species & \multicolumn{1}{|c|}{ Tentacle density } & \multicolumn{1}{|c|}{ Tentacle length } & Size of mucilage drops \\
\hline Byblis aquatica & Sparse & $\begin{array}{l}\text { Uniformly similar } \\
\text { in length, maybe the } \\
\text { shortest among the six } \\
\text { species }\end{array}$ & $\begin{array}{l}\text { Largest of all six } \\
\text { species }\end{array}$ \\
\hline Byblis guehoi & Dense & $\begin{array}{l}\text { Varied lengths, the } \\
\text { longest up to } 4 \times \text { the } \\
\text { length of the shortest }\end{array}$ & $\begin{array}{l}\text { Varies between forms, } \\
\text { but never as large as in } \\
\text { B. rorida }\end{array}$ \\
\hline Byblis filifolia & Dense & $\begin{array}{l}\text { Varied lengths, but not } \\
\text { as long nor as varied as } \\
\text { in B. guehoi }\end{array}$ & $\begin{array}{l}\text { Varies between forms } \\
\text { but never as large as in } \\
\text { B. rorida }\end{array}$ \\
\hline Byblis liniflora & Dense & $\begin{array}{l}\text { 2-3 different lengths but } \\
\text { not as varied as in } B . \\
\text { filifolia }\end{array}$ & $\begin{array}{l}\text { Larger than in } \\
\text { B. pilbarana but smaller } \\
\text { than in } B \text {. rorida }\end{array}$ \\
\hline Byblis rorida & $\begin{array}{l}\text { Denser than in } \\
\text { B. aquatica but not as } \\
\text { dense as B. liniflora }\end{array}$ & $\begin{array}{l}\text { 2-3 different lengths but } \\
\text { not as varied as in } \\
\text { B. filifolia }\end{array}$ & $\begin{array}{l}\text { Large, but still smaller } \\
\text { than in B. aquatica }\end{array}$ \\
\hline Byblis pilbarana & Dense & $\begin{array}{l}\text { and similar to } \\
\text { B. liniflora }\end{array}$ & Smallest of all \\
\hline
\end{tabular}

leaves can become reddish-purple in some forms, and the short tentacles with comparatively large mucilage droplets make for very beautiful plants, somewhat resembling frosted Christmas trees.

\section{Byblis filifolia}

A very variable species which inhabits areas that are seasonally damp but rarely inundated (as do all annual species other than B. aquatica). All forms produce large and showy flowers bearing anthers that are longer than (or at least equal in length to) the filaments - a characteristic shared with $B$. guehoi, $B$. pilbarana, and $B$. rorida. The most wonderful forms hail from the Pago region (Kimberley, Western Australia), reaching at least $60 \mathrm{~cm}$ in height with stout selfsupporting stems, as well as leaves that can exceed $20 \mathrm{~cm}$ in length. The stems can form branches, often with several growing points bearing numerous flowers simultaneously (Fig. 2). Other forms, including the rather inaptly-named $B$. 'Goliath' (a cultivar of B. filifolia), produce long but straggly stems and shorter leaves rarely exceeding $10 \mathrm{~cm}$ in length.

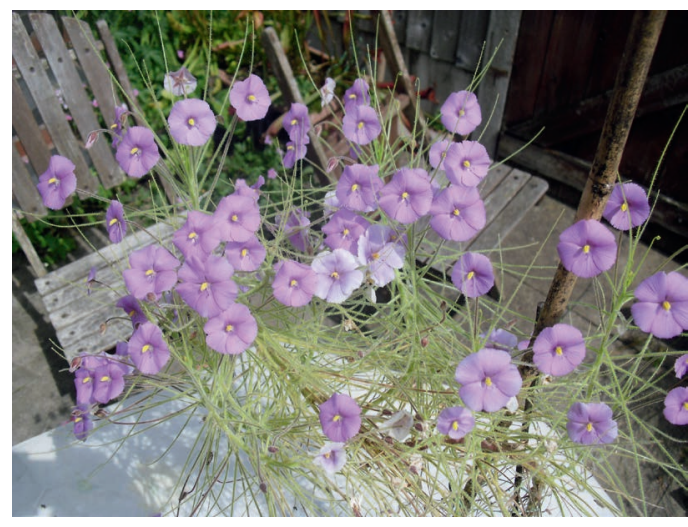

Figure 2: A single plant of the giant form of Byblis filifolia originating from the Pago Region, Kimberley, Western Australia. 


\section{Byblis guehoi}

This is surely one of the most spectacular of all carnivorous plants. Although rather similar in basic appearance to the shorter-leaved forms of B. filifolia, this species, when grown well, has stems which branch profusely. Individual plants can have dozens of growth points and more than 70 flowers open simultaneously. (Fig. 3)

\section{Byblis liniflora}

This widespread species is compact and densely covered in sticky glands. It has relatively small but pretty flowers, only a few of which

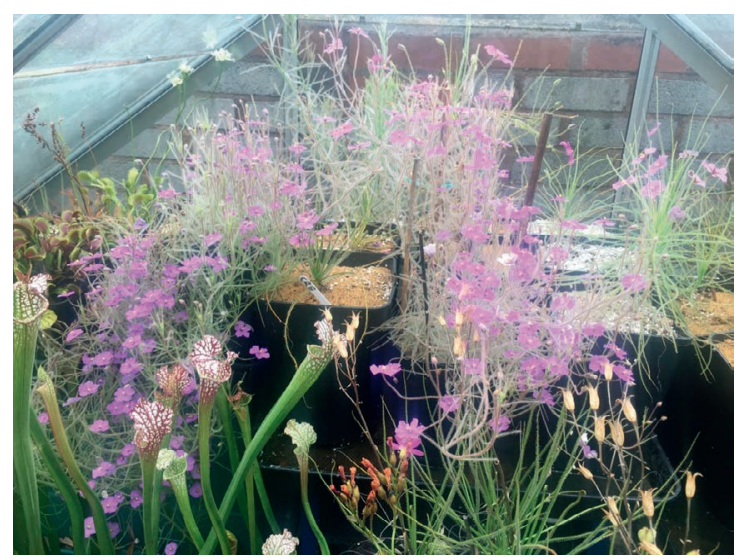

Figure 3: Byblis guehoi dominating a summer greenhouse. Also present in the picture are $B$. gigantea, B. lamellata, and B. filifolia, as well as several other species of carnivorous plants. usually open at any one time. The anthers are shorter than the filaments (a characteristic shared with B. aquatica).

\section{Byblis pilbarana}

Recently described, this species originates from the vicinity of the Great Sandy Desert in the Pilbara region of Western Australia, one of the hottest in all of Australia. On the basis of photographs taken on a field trip by Professor Hans Lambers, it seems that the range of the genus, probably represented by B. pilbarana, extends several hundred kilometers inland into the Karlamilyi National Park. Very delicate in appearance, its pedicels (flower stalks) are much longer than the leaves and tend to point skywards (Front Cover). Interestingly, specimens in habitat tend to have stocky stems with short internodes, whilst most cultivated specimens seem to become lanky over time.

\section{Byblis rorida}

This species is similar to the short-leaved forms of B. filifolia, but the growing point is covered in dewy sessile glands which, unlike the digestive glands, are clearly visible to the naked eye. The function of these dewy sessile glands is unknown. The beautiful flowers often have deeply serrated edges (Front Cover). There is a giant form originating from Lawrence, Dampier Peninsula, Kimberley, Western Australia, which has short internodes and can become quite bushy in appearance.

\section{Cultivation}

\section{Perennial species}

Getting started: Owing to the scarcity of plants for sale and to their delicate nature (not shipping well), most growers start with seeds. Fire often stimulates germination in nature, so GA3 treatment is recommended for germination in cultivation (GA3-free germination in cultivation is virtually unknown). We recommend a 4-5-day soak in GA3 (conc. 500 ppm), although smoke discs have been reported to be just as effective. Do-it-yourself fire-treatment is another option, but we find this method is unreliable and can result in much wastage of good seed.

Germination can take place in as little as 14 days. Seedlings initially develop very slowly and are very susceptible to damp-off. Survival rates are best when germinating under lights indoors (but 
not in a terrarium), although satisfactory results can be obtained in temperate regions in spring in a sunny greenhouse (and presumably on a very sunny windowsill or in a conservatory).

The perennial species are extremely difficult to grow in places such as Singapore where the ambient humidity is consistently high. Even seedlings that are placed at open and well-ventilated areas are excessively prone to dying off soon after germination, especially during monsoon season. To date, we are not aware of any growers who have successfully cultivated perennial Byblis to flowering size in the tropics, even though some have tried using air conditioners to lower the ambient humidity and temperature.

Substrate: An airy, sandy substrate is required, approximately 3:2:1 ratio of perlite : lime-free sand : moss peat works well for plants of all ages. The proportion of perlite can be increased. Sand may inhibit the ability of the roots of some seedlings to penetrate the surface of the substrate. Seedlings should be transplanted into pots $10 \mathrm{~cm}$ or so deep, but very carefully since they have surprisingly long and fine roots. Plantlets over $\sim 12 \mathrm{~cm}$ in height should be transplanted carefully into pots at least $20 \mathrm{~cm}$ deep. Adult plants appreciate a $1 \mathrm{~cm}$ top-layer of pure sand.

General conditions: Full sun is required, ideally in frost-free greenhouses, conservatories or south-facing windowsills (north-facing in the Southern Hemisphere) to replicate their Mediterranean climate. In temperate climates, plants should be overwintered indoors or in a heated greenhouse, preferably under lights. Stems will become increasingly yellowish and straggly over winter. For more information regarding long-term cultivation indoors under lights, refer to Anthony Bell's article in this same issue. Sometimes, an especially vigorous plant will sprout shoots from the base before the main stem is mature (Fig. 4).

Watering: Rainwater is preferred since hard tap water may kill plants. Seedlings and young plants can take very wet conditions. Adult plants can be watered through a tray system. Prior to replenishing, allow the tray to dry, especially in winter (it matters less in summer). Ideally, when plants are grown in the recommended deep pots, the topmost layer of sand on the soil surface should remain bone dry at all times, whilst the substrate below should remain damp.

Propagation: Best by seed. Flowers must be handpollinated with pollen from a genetically distinct individual. Vigorously (but gently) brushing the anthers will stimulate the release of pollen, which can then be transferred to the stigma of other flowers. A tuning fork is often said to be necessary to achieve pollen release, but a toothpick or similar item works equally well. Successful pollination will result in swollen fruit which eventually dries out. They must be pried open, since dried fruit will not open on their own in cultivation. Stem and root cuttings have also been reported to work.

Things to avoid: The primary challenge of growing perennial Byblis in the UK lies in getting the plants through our dark damp winters. Tall pots, airy substrate, and as much light as possible are the key factors for success. The following are to be avoided:

- Sodden substrate (especially around the crown).

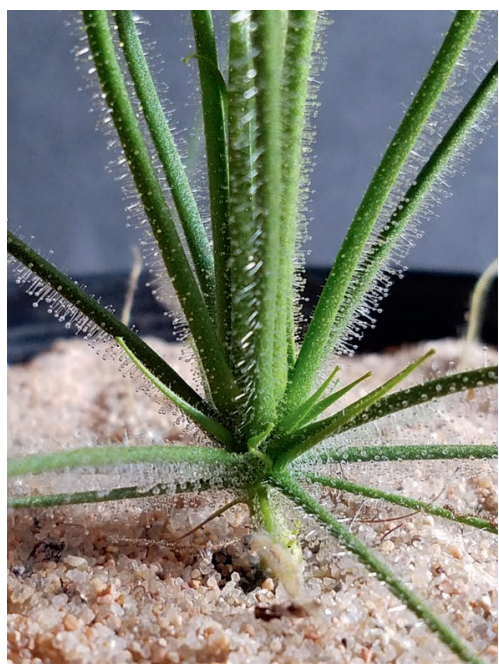

Figure 4: An especially healthy Byblis lamellata sprouting shoots from its base when the main stem is still young (courtesy of Anthony Bell). 
- Heavy substrate containing too much peat (the traditionally-recommended peat and sand mix is, in the longer term, a death sentence).

- Hard tap water.

- Lack of light, especially in humid winter conditions.

- Excessive heat, or freezing temperatures, in winter.

- Repotting in late summer, autumn, or winter - and careless repotting which breaks the long and very fragile roots.

\section{Pests:}

- Seedlings and young plants are very susceptible to attack from slugs and snails.

- Aphids can infest plants during the winter.

- Mealy bugs around the base of the stems, which can easily be removed by hand.

Feeding: Plants with limited access to prey seem to appreciate the application of bloodworm or flake fish food to the leaves. The leaves of very young plants can be killed by the application of too much food, especially bloodworms. It also pays to be aware that old or excess food may encourage fungal growth. Plants grown in greenhouses or outdoors usually catch an abundance of prey without intervention. Some growers have reported success with fertilizers, either by fertilizing the substrate with Osmocote, or by spraying the plants with a foliar feed such as MaxSea.

\section{Annual species}

Getting started: Again, most growers start from seed. All species (except $B$. liniflora) require GA3 or smoke treatment for reliable germination. A 1-2-day soak (500 ppm) will suffice. Bleach treatment is sometimes recommended, its benefits are unproven. All species inhabit very warm climates and grow in full sun. Therefore, it is best to germinate seeds in a heated and well-lit terrarium or propagator for growers outside of tropical regions.

Feeding: Lack of nutrition usually results in weak specimens. Very vigorous plants can be produced when frequently fed with crushed flake fish food, which can be sprinkled onto the tentacles once the leaves are $1 \mathrm{~cm}$ or so in length, or fragments of bloodworm. Leaves of young plants can wither if overfed, especially with bloodworm, but the latter can stimulate especially good growth. Plants grown outdoors in the tropics, or in greenhouses in other regions, usually catch plenty of prey of their own. Some growers have reported great benefit in using fertilizers. For example, Paul Young in England gave two B. aquatica plants weekly sprays of MaxSea, with spectacular results (Fig. 5). Steven Jones in Hawaii, and Siggi Hartmeyer in Germany, amongst others, have also demonstrated that pellets of Osmocote in the substrate can be of great benefit to the plants.

Watering: In temperate regions, all species are happy sitting in a cm or so of water at all times. Once adults, they are also very tolerant of quite dry spells. It has, how-

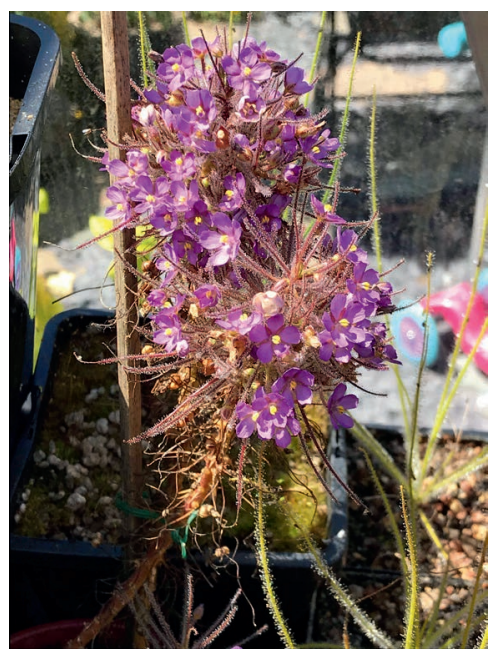

Figure 5: Two very robust and floriferous specimens of Byblis aquatica growing side-by-side. This spectacular growth seems to have resulted from regular foliar fertilization. The plants both produced great numbers of very short branches, each of which bore several flowers (courtesy of Paul Young), possibly a result of intense fertilization. 
ever, been observed by tropical growers that soaking wet media resulting from the tray system possibly leads to fasciation of adult B. guehoi and B. filifolia, especially when small pots $(10 \mathrm{~cm}$ or less) are used.

Where to grow them: In Singapore (and other areas with a similar climate, at least in the summer), the annuals grow well in full sun (protected from torrential rains) or at a sunny east or westfacing windowsill. Seedlings can be transplanted and placed into ambient conditions soon after germination as long as the media is kept moist. However, B. aquatica seedlings seem to appreciate much higher surrounding humidity until they are about 3 $\mathrm{cm}$ tall. Afterwards, the seedlings can be transplanted into their own pots and grown together with the rest of the annual species with several hours of direct sunlight outdoors or at the windowsill. In temperate regions, smaller species can be kept in heated terraria year-round, whilst the larger species will outgrow all but the largest terraria.

Species-specific guidance

Byblis aquatica: Grows best in a 3:2 mix of perlite : moss peat mix or 1:1 of perlite : LFS or live sphagnum. If well-fed, it can do well even in very shallow substrates (large plants can be obtained in only $2 \mathrm{~cm}$ of soil). In the UK, it is best kept for its entire life-cycle in a heated terrarium, although it will survive for several months in a summer greenhouse. It is self-fertile but will not usually produce seed without the anthers being teased. Inundated conditions are not required in cultivation.

Byblis filifolia and B. guehoi: The aim should be to induce plants to produce branches from the leaf axils (Fig. 6), which usually appear contemporaneously with the first flower-buds, resulting in huge and profusely-flowering specimens. A 3:1:1 substrate of perlite : moss peat : household compost for acidic plants works well. The extra nutrients of the compost appear to encourage branching. Very vigorous plants can also be obtained using a 3:2 substrate of perlite : LFS or live sphagnum, as long as the plants are well-fed.

To give B. filifolia and B. guehoi time to reach their full potential in temperate regions, it is best to germinate seeds in a terrarium or propagator in late winter or early spring. Frequent feeding with fish food and or bloodworms will result in vigorous plants which, in central England, can be placed in a greenhouse from the beginning of June, or a sunny windowsill a month earlier (Fig. 7). Large plants require $20 \mathrm{~cm}$ deep pots for the best long-term growth,

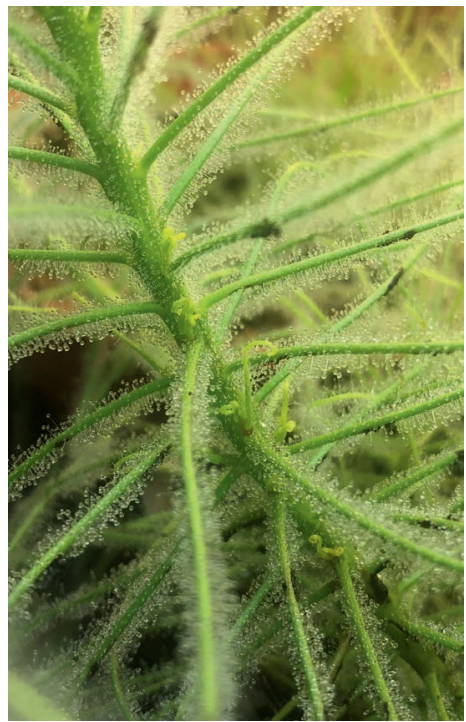

Figure 6: Byblis guehoi starting to produce side branches.

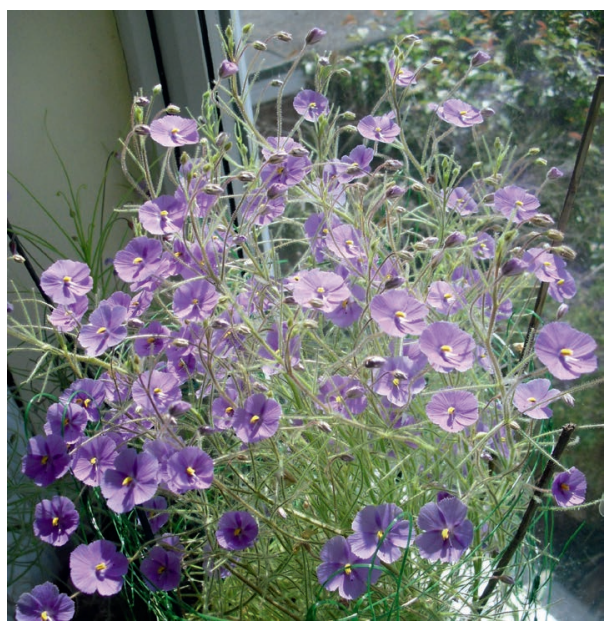

Figure 7: A single Byblis guehoi plant on a south-facing windowsill in summer, Birmingham, UK. 
although they can attain flowering size and set seed in small pots. They can be germinated in small peat pots, then, once larger, be placed inside deeper pots. To obtain seed, flowers must usually be cross-pollinated in the manner described for the perennial species. Adult plants are quite coldtolerant, surviving in England until mid-October in an unheated greenhouse, or until Christmas on a windowsill. They eventually become increasingly straggly until they are finished off by the short photoperiod. As a general benchmark for growers from regions with different climates, the average high in June in central England is around $19^{\circ} \mathrm{C}$, and the average low is around $10^{\circ} \mathrm{C}$.

In tropical regions, the best time to sow seeds of these species is during the coolest and/or wettest month of the year (December in Singapore). Plants will flourish for about 10 months, after which they grow too tall and lanky. Most growers in Singapore use 100\% LFS or 1:1 mix of perlite : LFS in large pots to encourage vigorous branching and thus spectacular plants.

Byblis liniflora, B. pilbarana, and B. rorida: These species will do well in a 3:2 mix of perlite : peat, or 4:2:1 of perlite : sand : peat, or even 1:1 of perlite : LFS or live sphagnum. They do best in pots at least $10 \mathrm{~cm}$ deep. $B$. liniflora is self-fertile and often produces copious amounts of freely germinating seed. B. pilbarana and $B$. rorida must be cross-pollinated in the manner described for the perennial species. They do not usually produce copious amounts of seed, so they need to be pollinated attentively. All three species will be fine on a windowsill or in an unheated greenhouse from June onwards in central England, but they tend to die well before B. filifolia and B. guehoi.

Propagation by cuttings: When mature plants start looking straggly, stem cuttings of about $6-8 \mathrm{~cm}$ can be taken using pair of sharp scissors. These portions of stem can be stuck into $100 \%$ loosely packed LFS or 1:1 ratio of perlite : LFS or even $100 \%$ perlite, leaving about $2 / 3$ of the stem above the media (Fig. 8). The cuttings should be placed in a very bright area or under artificial lighting where the humidity can be kept constant at about $50-70 \%$. When kept warm $\left(25-28^{\circ} \mathrm{C}\right)$, stem cuttings will produce roots within a week or two (Fig. 9). New side shoots usually emerge from the decapitated mother plant and continue their life cycle as if nothing had happened, sending out new flowers eventually (Fig. 10). With younger plants, cutting the main stem may cause it to turn brown and die. Maybe because of its thin stems, B. pilbarana doesn't seem to appreciate being propagated in this manner, but more tests need to be conducted on this relatively new species to find out if stem cuttings can be a dependable method of propagation.

\section{Things to avoid:}

- In terraria, plants do not like being too close to grow lights (perhaps due to excessively low humidity). However, if there is glass between the lights and the

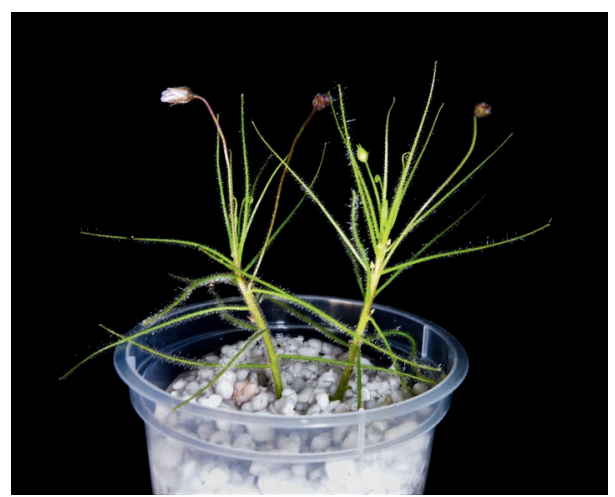

Figure 8: Stem cuttings of Byblis guehoi in $100 \%$ perlite.

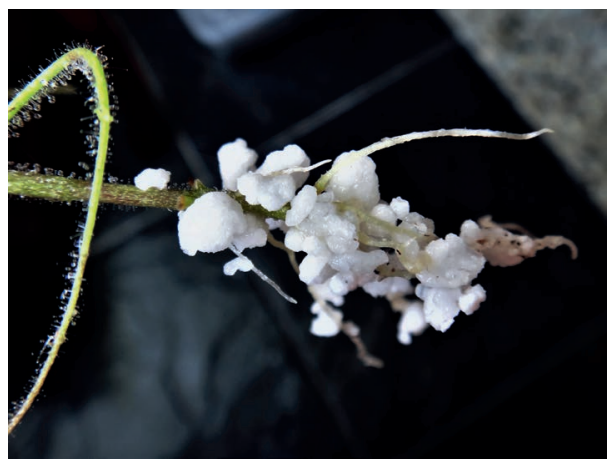

Figure 9: Roots of Byblis guehoi cutting in $100 \%$ perlite. 
growing space, they enjoy being very close to the lights.

- Plants struggle in heavy substrate containing too much peat. The traditionallyrecommended peat and sand mix gives very poor results.

- Hard tap water.

- Lack of light - the annual species grow in bright tropical sun.

- Frequent repotting. Seedlings can be carefully transplanted from seed trays to larger pots, but avoid repotting mature plants.

- Inbreeding amongst the non-self-fertile species. This can lead to infertile plants or a poor seed set, but can be averted by maintaining several plants of each species and carefully crossing them. Swapping seed with other growers is perhaps the most effective way to avoid inbreeding.

Pests: Seedlings and young plants are very

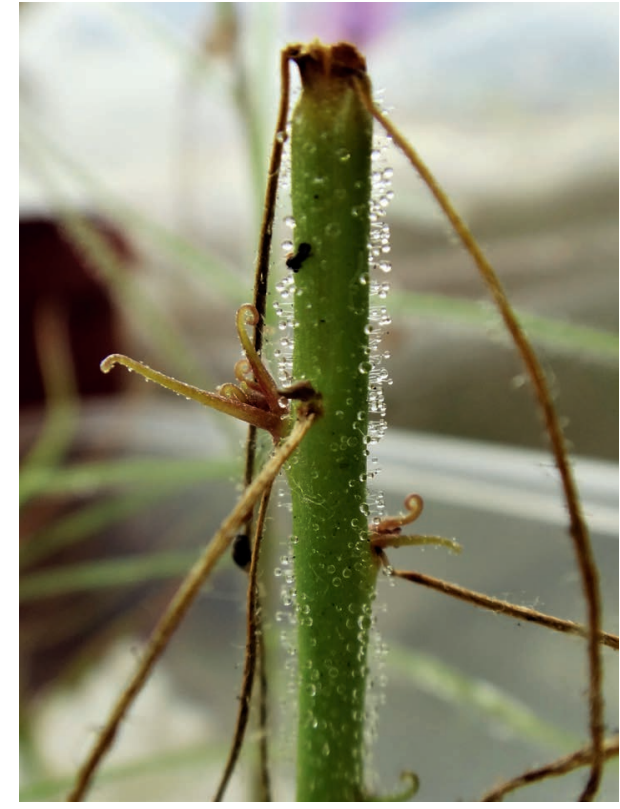

Figure 10: Side shoot produced on stem cutting of Byblis guehoi. susceptible to slug and snail attacks. Adults plants can be attacked by various pests when reaching the end of their life cycles, but, at least in temperate regions, adult plants are not susceptible to pests when in their prime. Adult plants are very prone to mealy bugs when grown in overly hot and humid conditions, especially after the flowering season. Sometimes the infestation can be so bad that the whole plant may be killed.

\section{Byblis Hybrids}

In Singapore, B. filifolia 'Goliath' was successfully crossed with B. guehoi in September 2011, the latter being the pollen donor. Germination rate was $>80 \%$ and the F1 hybrids were fertile and varied in characteristics: some were more like $B$. 'Goliath' (very tall, less branching) while others were more like B. guehoi (more compact, heavy branching). No further generations were raised, so this is certainly an area for future experimentation. The presence of hybrids between the annual species in the wild has not been reported. Hybrids between the perennial species have been reported in cultivation.

\section{Setocoris}

These fascinating insects inhabit all Byblis species in nature. They possess the amazing ability to crawl up and down the sticky glandular surfaces with virtual impunity, and they feed on insects captured by the plants. It is suspected that their droppings provide the plants with additional nourishment. The best-known of species of this little-studied genus is Setocoris bybliphilus, which inhabits $B$. gigantea. Juvenile $S$. bybliphilus bugs superficially resemble greenfly in color and shape. The short-lived adults are superficially similar in appearance to ants (Fig. 11). Allen Lowrie claims that the perennial species are better adapted to accommodate their resident Setocoris, since their leaves lack stalked glands on the upper surfaces, apparently providing convenient pathways for Setocoris 
to traverse the leaves and leave droppings for the plants' benefit. Setocoris are very easy to keep and breed, simply living on greenhousecultivated plants year-round. Many of them die during the winter, presumably having laid eggs on the plants, since the population usually explodes again in spring. At this time, they spread rapidly to any annual Byblis growing nearby, and also to neighboring Pinguicula, Drosophyllum, and some Drosera (e.g. D. regia). Pesticides must be avoided at all costs - winter problems with greenfly on perennial species seem to be the price of keeping these fascinating and little-studied insects.

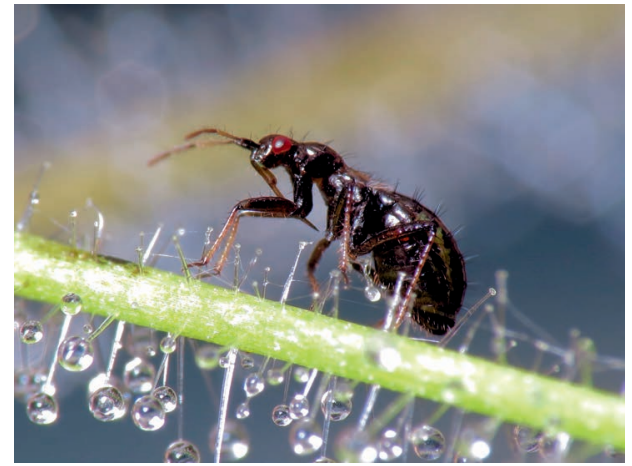

Figure 11: Setocoris bybliphilus on Byblis (courtesy of Stéphane Joly).

Acknowledgements: The authors would like to thank Greg Bourke and Anthony Bell for suggestions and comments on earlier drafts of this article, and to Fernando Rivadavia for his tireless reviewing, co-ordination and editing of this work. We are also extremely grateful to Anthony Bell, Paul Young, and Stéphane Joly for providing the photographs in figures 4, 5, and 11 respectively, and for granting permission for them to be used in this article. Additionally, we would like to extend our gratitude to Hans Lambers for sharing with us information pertaining to a 2002 field trip in which he photographed a Byblis species (most probably B. pilbarana) growing alongside Drosera finlaysoniana at Goose Whackers in the Karlamilyi National Park, Western Australia. We would also like to thank Allen Lowrie, who has done so much over so many years to introduce Byblis into cultivation, and to inform the world about this genus by publishing new species. A few other dedicated Byblis growers who have helped us tremendously over the years, and who we'd like to thank here, are Stefan Ippenberger, Maik Rehse, Gianni Marcantoni, Isao Takai, and Brian Barnes.

Suggested reading for the Byblis enthusiasts:

Bourke, G., and Nunn, R. 2012. Australian Carnivorous Plants. Redfern Natural History Productions. Poole, Dorset, England: 1-197. [Contains numerous rare shots of various Byblis species in habitat.]

Lowrie, A. 2013. Carnivorous Plants of Australia Magnum Opus, Volume 1. Redfern Natural History Productions. Poole, Dorset, England: 1-458. [As well as numerous habitat photos and specific sections on each species, there is also a section which covers Setocoris bugs.]

McPherson, S. 2008. Glistening Carnivores, The Sticky-Leaved Insect-Eating Plants. Redfern Natural History Productions. Poole, Dorset, England: 1-392. [An excellent summary of the genus.]

McPherson, S. 2010. Carnivorous Plants and their Habitats, Volume 2. Redfern Natural History Productions. Poole, Dorset, England: 725-1442. [Contains a summary of the genus very similar to that in McPherson's 2008 text (above).] 


\section{CARNIVOROUS PLANT NEWSLETTER}

Journal of the International Carnivorous Plant Society

Volume 48, No. 2

June 2019

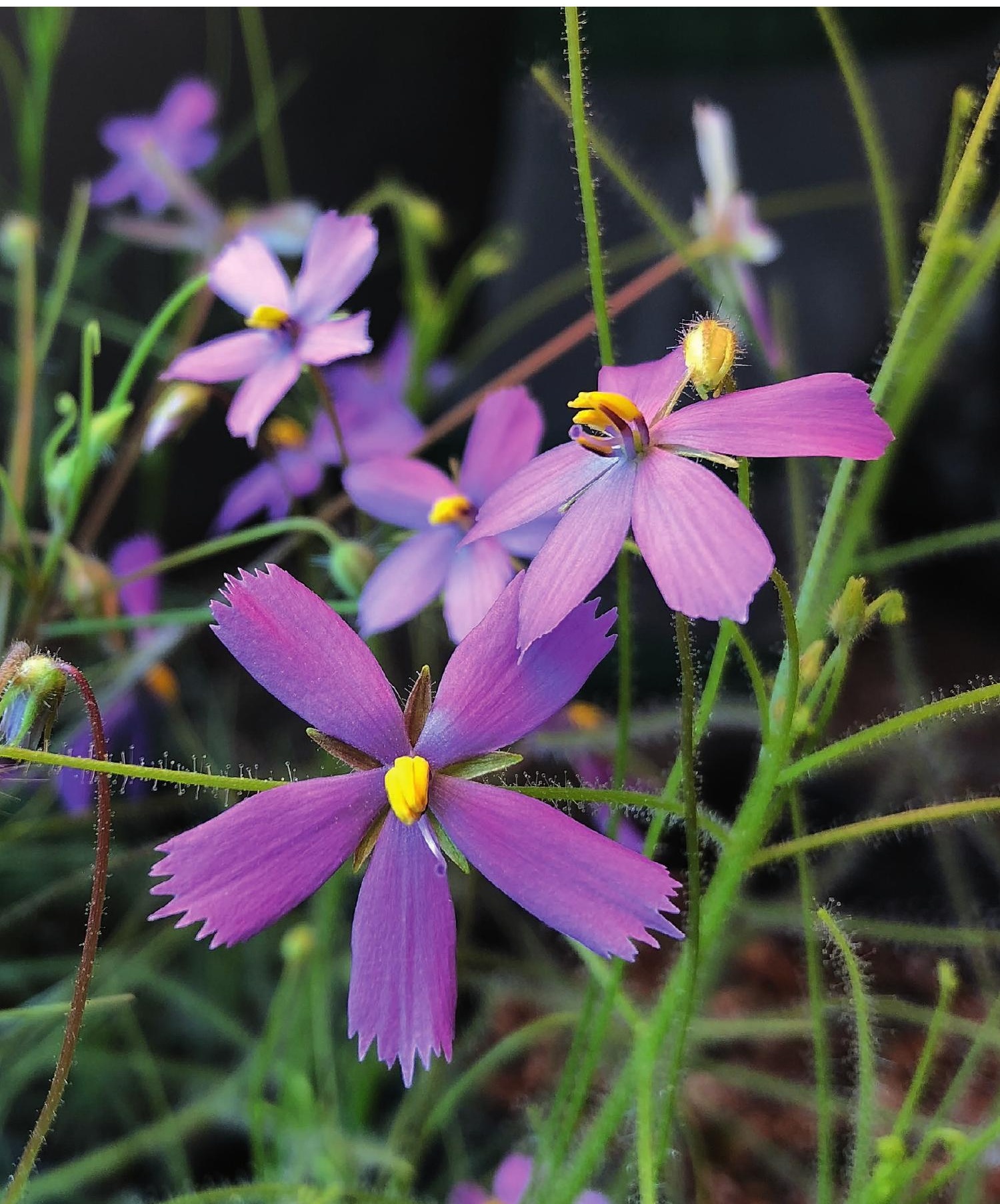




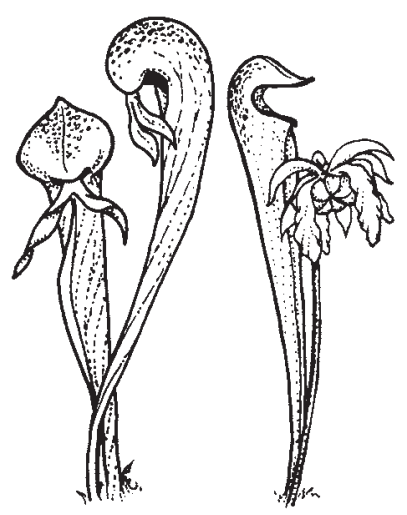

\section{CARNIVOROUS \\ PLANT \\ NEWSLETTER}

Journal of the International

Carnivorous Plant Society

www.carnivorousplants.org

Volume 48, Number 2 June 2019

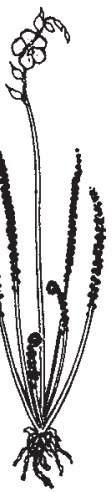

Front Cover: The beautiful flowers of Byblis rorida (center left) and Byblis pilbarana (center right). Photo by Gregory Allan. Article on page 79.

Back Cover: Byblis gigantea. Grown indoor from seed by Anthony Bell. Article on page 89.

Carnivorous Plant Newsletter is dedicated to spreading knowledge and news related to carnivorous plants. Reader contributions are essential for this mission to be successful. Do not hesitate to contact the editors with information about your plants, conservation projects, field trips, or noteworthy events. Advertisers should contact the editors. Views expressed in this publication are those of the authors, not the editorial staff.

All correspondence regarding dues, address changes and missing issues should be sent to the Membership Coordinator at the ICPS. Do not send such correspondence to the editors. Checks for subscriptions should be made to the International Carnivorous Plant Society in US funds. Dues, including a subscription, are \$30 per year.

International Carnivorous Plant Society, Inc.

2121 N. California Blvd., Suite 290

Walnut Creek, CA 94596-7351, USA

icps@carnivorousplants.org

President

Vice President

Secretary

Treasurer

Board Member

Board Member

Board Member

Membership Coordinator

Webmaster

Media Coordinator

Seed Bank Manager

CPN Editors

Managing Editor

Editor

Editor

Editor

Science Editor

Science Editor

Science Editor
Richard Nunn, richardnunn@carnivorousplants.org
John Brittnacher, john@carnivorousplants.org
Cindy Slezak, cindy@carnivorousplants.org
Daniela Ribbecke, daniela@carnivorousplants.org
Brent Jones, Conservation Director, brent@carnivorousplants.org
Jan Schlauer, Cultivar Registrar, jan@carnivorousplants.org
BobZiemer, bob@carnivorousplants.org
Cindy Slezak, cindy@carnivorousplants.org
John Brittnacher, john@carnivorousplants.org
Chad Williams, chad@carnivorousplants.org
Joe Griffin, joe@carnivorousplants.org
editor@carnivorousplants.org
Bob Ziemer
Barry Rice
Karl Herold
John Brittnacher
Andreas Fleischmann
Fernando Rivadavia
Jan Schlauer

Date of effective publication of the March 2019 issue of Carnivorous Plant Newsletter: January 30, 2019.

The ICPS is the International Cultivar Registration Authority (ICRA) for the names of cultivated carnivorous plants according to the International Code of Nomenclature for Cultivated Plants. Send relevant correspondence to the ICPS, Inc.

Carnivorous Plant Newsletter is published quarterly in March, June, September, and December by the ICPS, Inc., 2121 N. California Blvd., Suite 290, Walnut Creek, CA 94596, USA. Periodicals postage paid at Walnut Creek, CA and additional mailing offices. Postmaster: Send address changes to ICPS, Inc., 2121 N. California Blvd., Suite 290, Walnut Creek, CA 94596, USA. Printed by Allen Press, Inc., 810 E. 10th Street, Lawrence, KS 66044. Logo and masthead art: Paul Milauskas. (C) 2019 International Carnivorous Plant Society. All rights reserved. ISSN \#0190-9215 